\title{
Epidemiology of Simian Polyomavirus SV40 in Different Areas of Russian Federation (RF)
}

\author{
B. Lapin and M. Chikobava \\ Research Institute of Medical Primatology of the \\ Russian Academy of Medical Sciences, Sochi
}

Russia

\section{Introduction}

DNA-containing polyomavirus SV40 was isolated in 1961 from poliovaccine prepared on kidney cell culture of M.mulatta naturally infected with this virus. Main part of poliovaccines (IPV and OPV) was contaminated with SV40. From 1955 till 1963 hundred millions of people in USA, Russia (USSR), and in some other countries were immunized with contaminated SV40 Salk and Sabin vaccine and a lot of people became carriers of SV40. This virus was detected also in some human tumors. Epidemiological researches were not carried out in Russia before 2009. By present time possibility and ways of SV40 excretion into environment and possibility of its horizontal spreading is established. From the beginning of 60s (in Russia a little bit later) vaccines were free from SV40 contamination. In this article the data about SV40 infection of population in Moscow, St. Petersburg, in some cities of the Black Sea coast of Caucasus, in Novosibirsk and in one area of Krasnoyarsk region are presented., Analysis of the source of SV40 people infection is performed.

Small size DNA virus was isolated from mice in 1953. The virus was called "polyomavirus" SV40 (Gross, 1951; Gross, 1953). because it was able to produce multiple malignant tumors in newborn rodents.

Simian SV40 was the second discovered polyomavirus. It was isolated in 1961 from poliovaccine propagated on M.mulatta kidney cell cultures naturally infected with SV40 as it was established later (Eddy et al., 1961; Sweet \& Hilleman, 1960).

SV 40 is a small DNA virus which does not have envelope; its capsid consisted of 72 capsomers. The size of virion is $45 \mathrm{~nm}$; the viral genome is represented by two-stranded DNA aprox. $5000 \mathrm{bp}$ long. On character of the changes caused in cell cultures, the virus also has received the name "vacuolating virus"(Sweet \& Hilleman, 1960; Butel et al., 1999).

During next years polyomaviruses were isolated from different animals including different monkey species and from humans with different pathology as well (Simon,2008; Gjoerup, 2010; Voevodin, 2009).).

In 1957 baboon polyomavirus was discovered (Gardner et al., 1989); polyovavirus of African green monkeys was discovered in 1979 (zur Hausen \& Giosmann, 1979), after that polyomaviruses of M.fascicularis and chimpanzee were discovered (but not isolated). Two 
human polyomaviruses BKV and JCV were firstly isolated in 1971: JCV from a patient with Progressive multifocal leukoencephalopathy (Padgett et al., 1971), BKV from patient with nephropathy (Gardner et al., 1971; Padgett et al., 1971).

Later 3 more polyomaviruses were isolated: $\mathrm{KI}, \mathrm{Wu}$ from respiratory tract and $\mathrm{MCV}$ from rare malignant skin tumor - Merkel carcinoma (Feng et al., 2008)

Among human viruses such ubiquitous viruses as JCV and BKV are widely known and are determined from 60 to $90 \%$ of cases in humans according to data of different authors (Knowles et al., 2006; Maginnis \& Atwood, 2009).

However many publications often contradictory were associated with simian polyomavirus SV40. The virus was unintentionally introduced into human populations together with poliovaccine contaminated with SV40 as it turned out later (Shah, 2007).

The middle 50s of the last century was marked by epoch-making event - creating of 2 types of poliovaccines: Salk formolvaccine (IPV) and live attenuated Sabin vaccine (OPV). More than 100 million people were immunized in USA beginning from 1956 till 1963 using the above mentioned 2 types of vaccines; more than 70 million people were immunized in Russia (USSR) in 1960 using Sabin vaccine (Fisher, 1999. Rizzo, 1999, Peden, 2008, Drozdov, 2005, Mironova et al., 2006). Significant amount of predominantly young people were immunized in different European countries (Shah \& Nathanson, 1976).

It is necessary to look back to the history of poliovaccine creation by Salk and Sabin. Both vaccines (Salk inactivated formolvaccine and Sabin live attenuated vaccine) were poliovirus propagated on M. mulatta kidney cell culture. Soon it was shown that in high percent of cases M.mulatta had been already infected with SV40 in natural conditions (Sweet \&Hilleman, 1960; Lapin et al., 1965). That is why many poliovaccine lots were contaminated with this virus. As it was found out later Salk method of vaccine preparation did not provide full inactivation of the vaccine (Carbone et al., 1997). As to the Sabin vaccine - it was initially contaminated with polyomavirus (Peden, 2008).

Zoonotic SV40 origin perhaps is beyond doubt but some authors advance an opinion in their publications about preexisting of this virus in humans (Levine, 1998; Geissler, 1985; Paracchini, 2005). This assumption could be supported if SV40 (or DNA sequences of this virus or antibodies to it) could be reliably detected in human materials obtained before mass poliovaccination. Some publications contain information about detection the antibodies to SV40 before beginning the vaccination against poliomyelitis (Geissler, 1985). It can be supposed that the virus could be introduced into human population from the countries of monkey natural habitat (Southeast Asia and India). Serological investigations revealed SV40 infection of Zoo workers and in workers of India companies exporting monkeys and contacting with animals. SV40 footprints were detected in their blood (Horvath, 1965; Engels et al., 2004; Shah, 1966). All this testifies the possibility of contact infection humans from animals carriers of the virus.(citation from: Vastad, JAMA, 2002, 288, 1337-1338). However the quantity of people infected with SV40 greatly increased particularly after beginning of mass poliovaccination which testifies this supposition.

Thus mass vaccination of millions of people with poliovaccine which made it possible to eradicate poliomyelitis as an epidemic disease simultaneously led to infection of people with simian polyomavirus SV40. 
In 1961 as it was mentioned above USA investigators revealed contamination of poliovaccine with simian (M.mulatta) virus SV40.

Serological investigation and PCR revealed antibodies to SV40 and virus DNA sequences in polio immunized people. To the researcher's surprise the antibodies to SV40 were also detected in not vaccinated people. In connection with this fact the researchers came out with a suggestion that in human populations virus can spread horizontally (Knowles et al., 2006) It has been shown that virus can excrete into surrounding with excrements, breast milk, sperm, that supports the assumption about the possibility of horizontal spreading of the virus (David, 2001; Martini, 1996; Vastag, 2002).

Some investigators described discovery of polyomaviruses in sewage and in sea and river waters which undoubtedly could be the source of horizontal spreading of infection in regions with high SV40 prevalence (Vastag, 2002; Bofill-Mas et al., 2009).

Appearance of people infected with SV40 after immunization with polio vaccine caused anxiety of physicians due to virus ability to induce malignant tumors in laboratory rodents. However absence of apparent increase of tumors in polio vaccinated people reduced the interest to SV40 in people. A new wave of anxiety and long lasting discussions continuing up to now was caused by discovery of DNA sequencing of SV40 in some human tumors. As a result great many contradictory publications appeared describing infection of people with this virus, its origin, ways of spreading and possible connection with human pathology (Carbone, 1994, 1997,1999; De Rizzo, 1998, 2001; Arrington, 2000; Tognon, 2001; Lednicky,2001; Bergsagel, 1992; Vilchez, 2002; Klein, 2002; Bocchetta, 2001; Lapin \& Chikobava, 2011; Cutrone et al., 2005; Carter et al., 2003; Hübner R. \& Van Marck E.2002; Martini et al., 1998; Barbanti-Brodane et al., 2004).

Some researchers considered discovery of SV40 in human blood and in tumors as artifact (Shah, 1976; Lopez-Rios, 2004; Manfredi, 2005; Mayall, 2003, and many others). Disagreement was caused mainly by high homology of SV40 with ubiquitous human polyomaviruses JCV and BKV and consequently with their immunologic and molecularbiological reactivity (Testa, 1998; Lopez-Rios, 2004; Heinsohn, 2005; Shah \& Nathanson, 1976; Shah, 2007; Carter et al., 2003). Some researchers denied infection people with SV40 and believed that discovered antibodies and DNA sequencing belong to human polyomaviruses JCV and BKV.

Because M.mulatta are carriers of polyomavirus SV40 in natural conditions WHO recommended to replace in manufacture poliovaccines kidneys of rhesus monkeys with kidneys of green monkeys not containing this virus. At the same time methods of vaccine decontamination were improved. It is possible to assert that in the period from 1960 till 1962 poliovaccine produced by USA, Great Britain, and some other European countries was free from SV40 contamination. However by that period of time hundred millions of people had been already immunized with contaminated SV40 vaccine in USA, Russia (USSR) and many other countries. In Russia (USSR) that produced vaccine for own needs and also for export to east European countries and countries of southeast Asia clearing vaccine from contamination happened some years later Chumakov et al., 1961;Chumarjvet al., 1963; Scovranek, 1961)

Vaccine produced in east countries was contaminated with SV40 till 1978 according to data of USA and English researchers who investigated SV40 contamination in poliovaccine 
samples produced in different time in different countries. Authors of the publication note that method of heat inactivation of the vaccine in the presence of $\mathrm{MgCl}_{2}$ inactivated SV40 not completely (Cutrone et al., 2005).

Epidemiological investigations carried out in different countries revealed infection of population with SV40. K. Leithner et al (2005) in Fig 4 of their article published a schematic map demonstrating data on infection of population with SV40 in European countries where contaminated SV40 vaccine was used and afterwards SV40 infection of population was revealed and also those countries where contaminated vaccine was also used but the population was not examined for SV40 infection. Such countries were Russia, Ukraine, Byelorussia, and some East European countries in which vaccination was carried out with OPV Sabin vaccine perhaps produced in Russia (USSR).



Fig. 1. Red color designates countries where contaminated SV40 vaccine was used and SV40 carriers were discovered (continuous coloring does not mean degree of prevalence). Shaded area designates countries where contaminated vaccine was also used but people were not tested for SV40 carriers. (Leithner 2005). See also Table 1.

Authors of this publication prepared a Table on the basis of literary data which helps to understand where the source of SV40 infection was. 


\begin{tabular}{|c|c|c|}
\hline Country & $\begin{array}{l}\text { Rating of contamination } \\
\text { of polio vaccines with } \\
\text { SV40 }\end{array}$ & $\begin{array}{l}\text { Vaccines, vaccination programs and } \\
\text { origin of vaccines }\end{array}$ \\
\hline Albania & Positive & $\begin{array}{l}\text { Contaminated Russian vaccine (OPV) } \\
\text { used since } 1960 \text { (Chumakov et al, } \\
\text { 1961;Chumakov et al, 1963; Shah \& } \\
\text { Nathanson, 1990; Levine et al, 1998). }\end{array}$ \\
\hline Austria & Negative & $\begin{array}{l}\text { Mass vaccinations with SV40-free British } \\
\text { vaccine (OPV) since winter 1961/62 } \\
\text { (Kundratitz, 1962; Friza, 1962) }\end{array}$ \\
\hline Bulgaria & Positive & $\begin{array}{l}\text { Contaminated Russian vaccine (OPV) } \\
\text { used since } 1960 \text { (Chumakov et al, 1961; } \\
\text { Chumakov et al, 1963; Shah \& } \\
\text { Nathanson, 1990; Levine et al, 1998). }\end{array}$ \\
\hline CSSR & Positive & $\begin{array}{l}\text { Since 1960: limited use of IPV, mass } \\
\text { vaccinations with OPV, partly with } \\
\text { contaminated Russian vaccine } \\
\text { (Chumakov et al, 1961; Chumakov et al, } \\
\text { 1963; Shah \& Nathanson, 1990; Levine et } \\
\text { al, 1998; Skovranek,1961; Chron Wld } \\
\text { Hlth Org, 1960) }\end{array}$ \\
\hline Denmark & Positive & $\begin{array}{l}\text { Vaccinations from } 1955 \text { with widely } \\
\text { contaminated Danish vaccine (IPV), } \\
\text { SV40-free from } 1963 \text { (Engels, 2003). A } \\
\text { combined schedule was introduced in } \\
1968 \text { (Murdin et al, 1996). }\end{array}$ \\
\hline Finland & Negative & $\begin{array}{l}\text { Mass vaccinations since } 1957 \text { with SV40- } \\
\text { free Belgium vaccine (IPV) (Hirvonen, } \\
\text { 1999). Finland has never used OPV on a } \\
\text { routine basis (Murdin et al, 1996) }\end{array}$ \\
\hline Germany East & Positive & $\begin{array}{l}\text { Contaminated Russian vaccine (OPV) } \\
\text { used since } 1960 \text { (Geissler, 1983; } \\
\text { Chumakov et al, 1963; Shah \& Nathanson } \\
\text {,1976; Prog Med Virol, 1990; Levine et } \\
\text { al,1998, Belian \& Rademacher, 1961). }\end{array}$ \\
\hline Hungary & Positive & $\begin{array}{l}\text { Since 1957: limited use of IPV, mass } \\
\text { vaccinations with vaccines from the US, } \\
\text { Canada, Hungary and Russia (also OPV) } \\
\text { (Chumakov et al, 1963; Shah \& } \\
\text { Nathanson, 1976; Geissler, 1990; Levine } \\
\text { et al, 1998) }\end{array}$ \\
\hline
\end{tabular}




\begin{tabular}{|c|c|c|}
\hline Norway & Positive & $\begin{array}{l}\text { Vaccinations started } 1956 \text { with Danish } \\
\text { vaccine (IPV); since } 1957 \text { potentially } \\
\text { contaminated U.S.vaccine (IPV) (Thu et } \\
\text { al, 2006), change to OPV from } 1967 \text { to } \\
\text { 1979, then back to IPV from } 1979 \\
\text { onwards (Murdin et al, 1996). }\end{array}$ \\
\hline Poland & Unclear & $\begin{array}{l}\text { Mass vaccinations (OPV) since } 1958 \text { with } \\
\text { Koprowski strain live vaccine [94]; } \\
\text { vaccine was claimed to be Russian made } \\
\text { (Minor et al, 2003), but Russian vaccines } \\
\text { were derived from Sabin's strain } \\
\text { (Chumakov et al, 1961) }\end{array}$ \\
\hline Russia (USSR) & Positive & $\begin{array}{l}\text { Mass vaccinations since } 1959 \text { with } \\
\text { contaminated Russian vaccine (OPV). A } \\
\text { small proportion of persons were } \\
\text { vaccinated with IPV at the beginning of } \\
\text { the mass vaccinations (Chumakov et al, } \\
\text { 1961; Chumakov et al, 1963; Shah \& } \\
\text { Nathanson, 1976; Levine et al, } \\
\text { 1998;Chron Wld Hlth Org 1960). }\end{array}$ \\
\hline Spain & Unclear & $\begin{array}{l}\text { Mass vaccinations since } 1963 \text { with British } \\
\text { vaccine (OPV) [101]; British vaccines } \\
\text { were SV40-free since } 1962 \text { (Sangar et al, } \\
\text { 1999); in contrast some vaccines were } \\
\text { later claimed to have been contaminated } \\
\text { (De Sanjose et al, 2003). }\end{array}$ \\
\hline Sweden & Positive & $\begin{array}{l}\text { In } 1957 \text { potentially contaminated U.S. } \\
\text { vaccine (IPV), from } 1958 \text { SV40-free } \\
\text { Swedish vaccine (IPV). Sweden has } \\
\text { never used OPV (Murdin et al, 1996) }\end{array}$ \\
\hline Turkey & Negative & $\begin{array}{l}\text { Vaccination was not started before } 1970, \\
\text { at a time where polio vaccines were } \\
\text { required to be SV } 40 \text {-free (De Rienzo et al, } \\
\text { 2002). The type of the vaccine is unclear. } \\
\text { In a global poliomyelitis eradication } \\
\text { initiative starting in 1989, OPV was used. }\end{array}$ \\
\hline United Kingdom & Positive & $\begin{array}{l}\text { Vaccination started in } 1956 \text { with OPV } \\
\text { (Chron Wld Hlth Org, 1958; Chron Wld } \\
\text { Hlth Org, 1960). SV40-free since } 1962 \\
\text { (Rev Sanid Hi Publica, 1965) }\end{array}$ \\
\hline
\end{tabular}

Table 1. (Leithner, 2005) 
We were aimed at carrying out epidemiological investigation and determining infection of population with polyomavirus SV40 in different regions of Russia and also determine intensity and source of infection. Investigation was carried out mainly anonymously. Each sample was accompanied with information about the place from where the sample was delivered, sex and age of the person.

To determine SV40 infection of population in Russia we decided to determine virus DNA sequences in blood samples of persons of different sex and age delivered to us by different medical institutions from different regions of Russia. Investigation of biological samples for SV40 is rather difficult because standard PCR and immunological tests (IFA, western blotting) do not allow differentiation of SV40 from widely spread ubiquitous human polyomaviruses JCV and BKV which have cross-immunological and cross molecularbiological-reactivity with SV40 (Viscidi, 2003). That is why for SV40 detection we chose the recommended method Real Time PCR (RQ-PCR) with TaqMan probe addressed to the area with 9-nucleotid deletion distinguishing SV40 from JVC and BKV.

\section{Methods}

For PCR analysis $100 \mathrm{ul}$ of blood was put into a test tube containing EDTA and kept at 4० C until it was delivered to the laboratory for DNA extraction. After extraction DNA samples were kept at $-20^{\circ} \mathrm{C}$.

Genome of SV40 can be present in the cell in 2 forms: episomal or integrated into genome of host cell. Because of few SV40 copies in the sample the best method allowing detecting episomal forms of SV40 DNA in RQ-PCR are methods based on DNA sorption by $\mathrm{SiO}_{2}$. That is why we used modified GuSCN protocol (Boom et al., 1992, Testa et al., 1998) for extraction of DNA from whole blood.

Three hundreds microliters of solution containing 5 M GuSCN,1\% Triton X-100(v/v), 20 mM EDTA, $50 \mathrm{mM}$ Tris- $\mathrm{HCl}\left(\mathrm{pH}\right.$ 6,4), $10 \mathrm{ul} \mathrm{SiO}_{2}$ was added to the blood sample (100 ul) and incubated $15 \mathrm{~min}$, centrifugated and the sediment was washed once in $5 \mathrm{M} \mathrm{GuSCN}, 50 \mathrm{mM}$ Tris- $\mathrm{HCl}(\mathrm{pH} \mathrm{6,4)}$ and twice in $10 \mathrm{mM}$ Tris- $\mathrm{HCl}(\mathrm{pH} 7,3), 50 \mathrm{mM} \mathrm{NaCl}, 50 \%$ ethanol. The sample was desiccated in thermostat and DNA was eluted by TE-buffer $(10 \mathrm{mM}$ Tris- $\mathrm{HCl}$ ( $\mathrm{pH} 8,0), 1 \mathrm{Mm}$ EDTA). For PCR amplification 5 ul were used. Rest was kept at $-20^{\circ} \mathrm{C}$.

As it was mentioned above SV40 detection was carried out by RQ-PCR method with internal probe directed to SV40 genome region in 4517 position, characterized by deletion of 9 nucleotides distinguishing SV40 from viruses JCV and BKV. PCR was carried out on BioRad Thermocycler according to the following program: 5 min initial denaturation, then 8 $\mathrm{sec}$ at $94^{\circ} \mathrm{C}, 23 \mathrm{sec}$ at $60^{\circ} \mathrm{C}, 30 \mathrm{sec}$ at $72^{\circ} \mathrm{C}$, during 50 cycles. DNA extracted from M.mulatta blood was used as positive control. Water $5 \mathrm{ul}$ from opened test tube kept together with extracted DNA samples was used as negative control.

\section{Results}

In total 768 blood samples obtained from different cities and regions of Russian Federation (St. Petersburg - 56, Moscow - 50, Krasnodar region - 352, Novosibirsk - 108, Krasnoyarsk region - 202) have been investigated by RQ-PCR. Results of these investigations are presented in Table 2. 


\begin{tabular}{|l|c|c|c|}
\hline \multirow{2}{*}{ Region } & \multirow{2}{*}{$\begin{array}{c}\text { Number of } \\
\text { samples }\end{array}$} & $\begin{array}{c}\text { Absolute } \\
\text { number }\end{array}$ & $\%$ \\
\cline { 3 - 4 } & & 49 & 49 \\
Krasnodar region & 100 & 8 & 16 \\
Moscow & 50 & 8 & 14 \\
St. Petersburg & 56 & 32 & 29.6 \\
Novosibirsk & 108 & 64 & 26.7 \\
Krasnoyarsk region & 202 & \\
\hline
\end{tabular}

Table 2.

Because this investigation revealed a rather high number of SV40 carriers in Krasnodar region we decided to check the situation in Sochi and Adler (Table 3).

\begin{tabular}{|l|c|c|c|}
\hline \multirow{2}{*}{ Region } & Number of & \multicolumn{2}{|c|}{ Number of SV40 positive } \\
\cline { 3 - 4 } & samples & Absolute number & $\%$ \\
\hline Sochi & 102 & 44 & 43 \\
\hline Adler & 150 & 48 & 32 \\
\hline
\end{tabular}

Table 3.

To confirm the results of RQ PCR, and prepare amplicons for sequencing another sets (SV5/SV6) of primers directed to conservative region 173-bp length of SV40 T-ag were used. These PCR primers amplify a region of SV40 that could be distinguished from BK and JC viral DNA. (Testa et al. 1998).

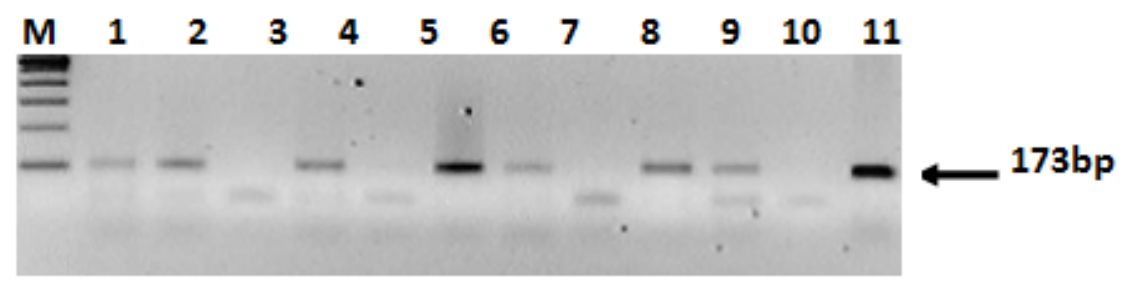

Fig. 2.

The ethidium bromide-stained 2.5\% agarose gel shows the PCR products of 9 blood samples, some of which are SV40 positive. N10(-) control (water), $11(+)$ control (DNA extracted from blood of SV40+ positive M. mulatta).

The obtained samples were sequenced on a ABI Prism 377 sequenator. Result of sequencing confirmed belonging of amplified regions to SV40.

We believe that the results can be corrected both towards the increase and towards reduction on the basis of age, sex and other factor analyzes of representative groups.

Nevertheless obtained material allows drawing some conclusions. High percent of SV40 infected children in Sochi and Krasnodar region at the age of 10 years who were immunized with poliovaccine reliably free from contamination with this virus definitely testifies horizontal way of contamination. 
Numerous publications are devoted to polyomavirus problem and a great part of them to SV40 problem: reliability or unauthenticity of SV40 detection in healthy people, in human neoplasm, SV40 role in tumor emergence, SV40 origin and ways of spreading are discussed. In a great degree a lot of publications are connected with scandalous character of the problem - SV40 introduction into human population during immunization against poliomyelitis.

Despite the fact that preparing vaccines on rhesus kidney cell cultures was stopped about 30 years ago SV40 carrying is still determined in high percent of cases in healthy persons and also in some malignant human neoplasm (brain tumors, mesotheliomas, osteosarcomas etc.).

Polyomavirus SV40 has been detected practically on all continents (Fig. 2). After introduction it into human population it should be considered as human virus - man has become its reservoir. The virus circulates among people, spreading horizontally, excretes into surrounding, pollutes it and this is perhaps a very important factor of its epidemiology.

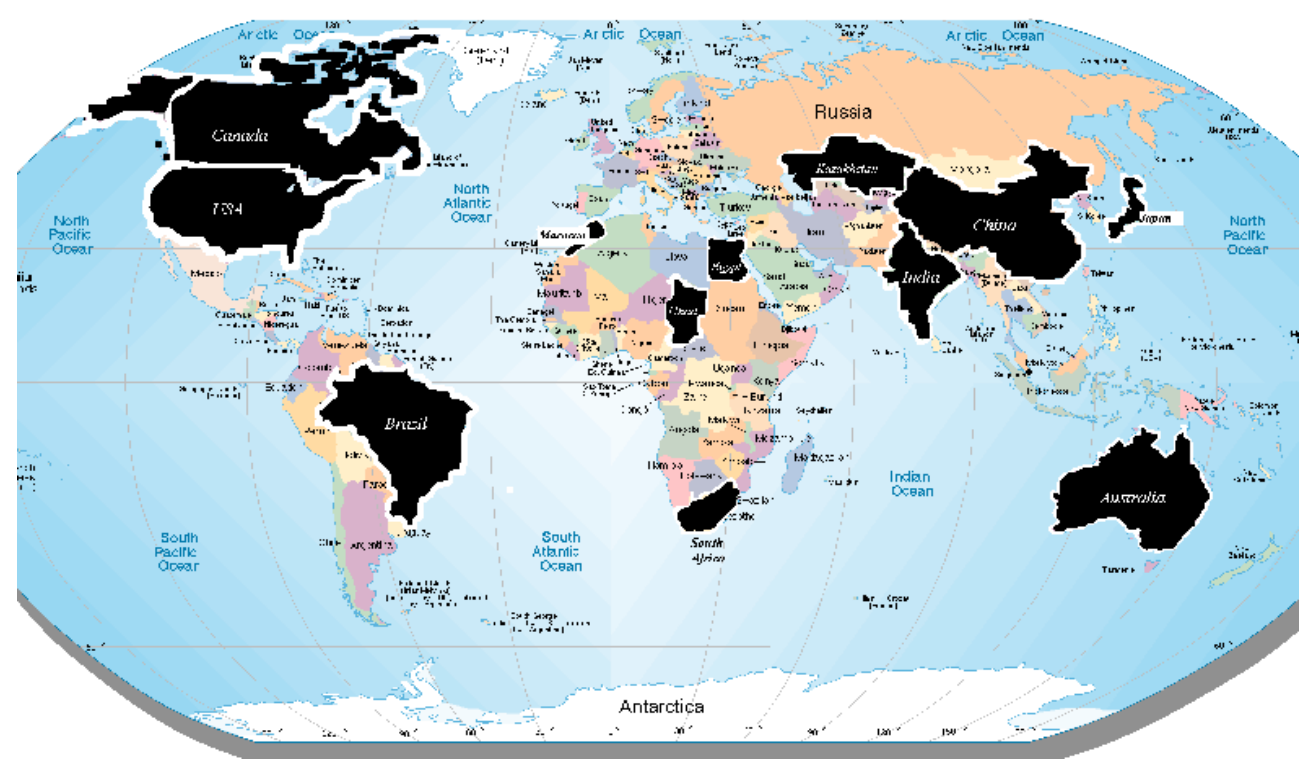

Fig. 3. SV40 infection of population was discovered on all Continents. Black color designates countries where SV40 carriers were discovered. However it does not mean the prevalence of SV40 infection.

\section{Conclusion}

In this article data on analysis of SV40 polyomavirus contamination of population in some regions of Russia are presented. Infection was detected by PCR in real time (RQ-PCR) with TaqMan probe directed to the site of 9 nucleotide deletion distinguishing SV40 from ubiquitous human viruses JCV and $\mathrm{BKV}$, The source of infection was mainly vaccination 
with Sabin OPV vaccine contaminated with SV40. Virus SV40 was detected in archive vaccine samples produced in East European countries before 1978 because heating with $\mathrm{MgCl}_{2}$ did not free the vaccine from SV40 contamination. Infection rate was investigated in 5 Russian regions: Russia (Moscow, St. Petersburg, cities of the Black Sea coast, Novosibirsk and Krasnoyarsk region).

The highest values were detected on the Black Sea and the lowest in St. Petersburg. Presence of SV40 in children vaccinated with reliably decontaminated vaccine confirms possibility of horizontal spreading of the virus. According to reference data contamination of population was revealed on all Continents.

Despite the fact that preparing polio vaccine on culture of M.mulatta kidney cells was stopped 30 years ago SV40 carriage still exists in healthy people in rather high percent and also in human malignant neoplasms practically in all countries, on all Continents (Basetse, 2002; Leithner et al., 2006; Minor et al., 2003; Zekri et al., 2007; Dang-Tan et al., 2004). Polyomavirus SV40 was introduced into human population and should be considered as human virus. Man has become its reservoir. The virus circulates among people, spreads horizontally, excretes into environment and pollutes it and this is an important factor in its epidemiology.

Perhaps true value of SV40 prevalence in different regions can be established at examination of randomized groups generated on age, sex, place of residing, conditions of life and cultural skills.

\section{References}

Arrington AS, Lednicky JA, \& Butel JS (2000): Molecular characterization of SV40 DNA in multiple samples from a human mesothelioma. Anticancer Res. 20: 879 - 884, ISSN 0250-7005

Barbanti-Brodano G, \& Tognon M (1996): SV40 early region and large T antigen in human brain tumors, peripheral blood cells, and sperm fluids from healthy individuals. Cancer Res. 56: 4820 - 4825, ISSN 0008-5472

Basetse HR, Lecatsas G, \&Gerber LJ.(2002) An investigation of the occurrence of SV40 antibodies in South Africa. S Afr Med J. Oct;92(10):825-8, ISSN 02569574

Belian W \& Rademacher I (1961): Vaccination with live poliovirus vaccine in the German Democratic Republic. In The control of poliomyelitis by live poliovirus vaccine Edited by: Weissfeiler J. Budapest, Akademiai Kiado; 53-56.

Bergsagel DJ, Finegold MJ, Butel JS, Kupsky WJ, \& Garcea RL(1992): DNA sequences similar to those of simian virus 40 in ependymomas and choroid plexus tumors of childhood. N. Engl. J. Med. 326: 988 -993, ISSN 0028-4793

Bocchetta M, Di Resta I, Powers A, Fresco R, Tosolini A, Testa JR, Pass HI, Rizzo P, \& Carbone M (2000) : Human mesothelial cells are unusually susceptible to simian virus 40-mediated transformation and asbestos cocarcinogenicity. Proc. Natl. Acad. Sci. 97: 10214 -10219. 
Boom R, Sol CJ, Salimans MM, Jansen CL, Wertheim-van Dillen PM, \& van der Noordaa J (1990): Rapid and simple method for purification of nucleic acids. J.Clin. Microbiol. 28, 495- 50, ISSN 0095-1137

Brown F, Lewis AM (eds) (1998): Simian virus 40 (SV40): A possible human polyomavirus. Dev Biol Stand. Basel, Karger, vol 94, ISSN 0301-5149

Butel JS, Lednicky JA. (1999): Cell and molecular biology of simian virus 40: implications for human infections and disease. J. Natl. Cancer .Inst. 91: 119- 134, ISSN10526773

Carbone M, Pass HI, Rizzo P, Marinetti M, Di Muzio M, Mew DJ, Levine AS, \& Procopio A. (1994) Simian virus 40-like DNA sequences in human pleural mesothelioma. Oncogene 9: 1781-1790, ISSN 0950-9232

Carbone M, Rizzo P, \& Pass HI (1997): Simian virus 40, poliovaccines and human tumors: A review of recent developments. Oncogene 15: 1877- 1888, ISSN 0950-9232

Carbone M. (1999)Simian virus 40 and human tumors: It is time to study mechanisms. J. Cellular Biochemistry 76: 189- 193, ISSN 0733-1959

Carter JJ, Madeleine MM, Wipf GC, Garcea RL, Pipkin PA, Minor PD \& Galloway DA (2003)Lack of serologic evidence for prevalent simian virus 40 infection in humans. J Natl Cancer Inst. Oct 15;95(20):1522-30, ISSN 1052-6773,

Chron Wld Hlth Org 1958, 12:163-166. Four years of poliomye,litis research, ISSN 10103090,

Chron Wld Hlth Org 1960, 14:137-142. Live poliovirus vaccine, ISSN 10103090 ,

Chron Wld Hlth Org, 1960, 14:142-144. Live poliovirus vaccination in the USSR, Poland and Czechsolovakia, ISSN 1010-3090,

Chron Wld Hlth Org 1960, 14:462-468. Poliomyelitis prevention, ISSN 1010-3090

Chumakov MP, Voroshilova MK, Drozdov SG, Dzagurov SG,Lashkevich VA, Mironova LL, Ralph NM, Gagarina AV, Dobrova IN, Ashmarina EE, Shirman GA, Fleer GP, Tolskaya EA, Sokolova IS, Elbert LB \& Sinyak KM (1961): Some results of the work on mass immunization of the population in the soviet union with live poliovirus vaccine from Albert S. Sabin's strains. In The control of poliomyelitis by live poliovirus vaccine Edited by: Weissfeiler J. Budapest,Akademiai Kiado, p.19-39.

Chumakov MP. (1961a)Some results of mass immunization of the population of the Soviet Union against poliomyelitis with live vaccine from Sabin strains.Vestn Akad Med Nauk SSSR. 16(4):30-43. Russian, ISSN 0869-6047

Chumakov MP.(1961b) Some results of the work on mass immunization in the Soviet Union with live poliovirus vaccine prepared from Sabin strains.Bull World Health Organ. 25:79-91, ISSN 0042-9686

Chumakov MP, Dzagurov SG, Lashkevich VA, Grachev VP, Mironova LL, Ralf NM \& Elbert LB (1963): Methods and results of preparing live poliovirus vaccine without SV40 impurities. In: Poliomyelitis and other enterovirus infections : . Proc.of the $2^{\text {nd }}$ scientific session of the Moscow, Institute of Poliomyelitis and Viral Encephalitides; p.201-202, Moscow.

Cicala C, Pompetti, \& Carbone M (1993). SV40 induces mesotheliomas in hamsters. Am. J. Pathology 142: 1524- 1533, ISSN 0002-9440 
Cutrone R, Lednicky J, Dunn G, Rizzo P, Bocchetta M, Chumakov K, Minor P, \& Carbone M.(2005) Some Oral Poliovirus Vaccines Were Contaminated with Infectious SV40 after 1961. Cancer Res 65(22): 10273-10279, ISSN 0008-5472

Dang-Tan T, Mahmud SM, Puntoni R \& Franco EL. (2004) Polio vaccines, Simian Virus 40, and human cancer: the epidemiologic evidence for a causal association. Oncogene. Aug 23;23(38):6535-40, ISSN 0950-9232

David H, Mendoza S, Konishi T, \& Miller CW (2001): Simian virus 40 is present in human lymphomas and normal blood. Cancer Lett 162: 57- 64, ISSN 03043835

De Rienzo A, Tor M, Sterman DH, Aksoy F, Alblda SM, \& Testa JR. (2002)Detection of SV40 DNA sequences in malignant mesothelioma specimens from the United States, but not from Turkey. J. Cell. Biochem. 84(3):455- 459, ISSN 0733-1959

De Sanjose S, Shah KV, Domingo-Domenech E, Engels EA, Fernandez DS, Alvaro T, GarciaVillanueva M, Romagosa V, Gonzalez-Barca E \& Viscidi RP (2003): Lack of serological evidence for an association between simian virus 40 and lymphoma. Int J Cancer 104:522-524, ISSN 0020-7136

David H, Mendoza S, Konishi T \& Miller CW (2001). Simian virus 40 is present in human lymphomas and normal blood. Cancer Lett. Jan 10;162(1):57-64, ISSN 03043835

Drozdov SG, Lashkevich VA. (2005) [The fiftieth anniversary of the M. P. Chumakov Institute of Poliomyelitis and Viral Encephalitides, Russian Academy of Medical Sciences]. vopr Virusol. May-Jun;50(3):4-7, ISSN 0507-4088

Eddy BE, Borman GS, Berkeley W, \& Young RD. (1961)Tumors induced in hamsters by injection of rhesus monkey kidney cell extracts. Proc. Soc. Exp. Biol. (NY) 107: 191197, ISSN 0037-0727

Engels EA, Katki HA, Nielsen NM, Winther JF, Hjalgrim H, Gjerris F, Rosenberg PS \& Frisch M (2003): Cancer incidence in Denmark following exposure to poliovirus vaccine contaminated with simian virus 40. J Natl Cancer Inst 95:532-539, ISSN 10526773

Feng H, Shuda M, Chang Y \& Moore PS (2008) Clonal integration of a polyomavirus in human Merkel cell carcinoma. Science. Feb 22;319(5866):1096-100. Epub 2008 Jan 17, ISSN 0036-8075

Fisher SG, Weber L, \& Carbone M (1999) Cancer risk associated with simian virus 40 contaminated polio vaccine. Anticancer Res. 19(3B): 2173- 2180, ISSN 02507005

Friza F (1961): Organisation und Durchfuhrung der ersten Schutzimpfung gegen Kinderlahmung mit Lebendvakzine nach Sabin in Osterreich im Winter 1961-1962. Mitt d osterr Sanitatsverw , 63:359-362.

Gallardo P.F, Clavel VL \& Galan GJ (1965): Resultados de la Campana nacional de vacunacion antipoliomielitica por via oral en Espana. Rev Sanid Hi Publica, 39:537561.

Gardner SD, Field AM, Coleman DV \& Hulme B(1971)New human papovavirus (B.K.) isolated from urine after renal transplantation. Lancet. Jun 19;1(7712):1253-7, ISSN 0099-5355 
Gardner SD, Knowles WA, Hand JF \& Porter AA(1989) Characterization of a new polyomavirus (Polyomavirus papionis-2) isolated from baboon kidney cell cultures. Arch Virol. 105(3-4):223-33, ISSN 0304-8608

Geissler E, Konzer P, Scherneck S, \& Zimmermann W(1985) Sera collected before introduction of contaminated polio vaccine contain antibodies against SV40. Acta Virologica 29: 420- 423, ISSN 0001-723X

Geissler E, Staneczek. W (1988) SV40 and human brain tumors. Archive fur Geschwulstforschung 58: 129- 134.

Geissler E (1990) SV40 and human brain tumors. Prog Med Virol 37:211-222, ISSN 0079$645 \mathrm{X}$

Gjoerup O, Chang Y (2010), Update on Human Polyomaviruses and Cancer. Adv Cancer Res. 106:1- 51, ISSN 0065-230X

Gross L (1951) "Spontaneous" leukemia developing in C3H mice following inoculation in infancy, with AK-leukemic extracts, or AK-embrvos. Proc. Soc. Exp. Biol. Med. 76: 27-32, ISSN 0037-9727

Gross L (1953) A filterable agent, recovered from Ak leukemic extracts, causing salivary gland carcinomas in C3H mice. Proc. Soc. Exp. Biol. Med. Jun; 83(2):414-21, ISSN 0037-9727

zur Hausen H, Gissmann L (1979) Lymphotropic papovaviruses isolated from African green monkey and human cells. Med Microbiol Immunol. Aug;167(3):137-53, ISSN 03008584

Heinsohn S., Golta S., Abisch H., \& zur Stadt U (2005), Standardized detection of Simian virus 40 by real-time quantitative polymerase chain reaction in pediatric malignancies. Haematologica 90: 94- 99, ISSN 0390-6078

Hirvonen A, Mattson K, Karjalainen A, Ollikainen T, Tammilehto L,Hovi T, Vainio H, Pass HI, Di Resta I, Carbone M \& Linnainmaa K (1999): Simian virus 40 (SV40)like DNA sequences not detectable in finnish mesothelioma patients not exposed to SV40-contaminated polio vaccines. Mol Carcinog 26:93-99, ISSN 08991987

Horvath LB (1965), Incidence of SV40 virus neutralizing antibodies in sera of laboratory workers. Acta Microbiol. Acad. Sci. Hung 12(2):201-205, ISSN 0001-6187

Hübner R,Van Marck E. Reappraisal of the strong association between simian virus 40 and human malignant mesothelioma of the pleura (Belgium) (2002) Cancer Causes Control Mar 13 (2):121-9, 11936818.

Jasani B, Cristaudo A, Emri SA, Gazdar AF, Gibbs A, Krynska B, Miller C, Mutti L, Radu C, Tognon M, Procopio A. Association of SV40 with human tumors. Semin Cancer Biol. 2001; 11:49- 61, ISSN 1044-578X

Klein G, Powers A, \& Croce C (2002): Association of SV40 with human tumors. Oncogene 21: 1141-1149, ISSN 0950-9232

Knowles WA (2006) Discovery and epidemiology of the human polyomaviruses BK virus (BKV) and JC virus (JCV). Adv. Exp, Med, Biol. 577:19- 45, ISSN 00652598

Kundratitz K (1962): Akutelle Impfprobleme. Mitt d osterr Sanitatsverw 63:192198.

Martini F, Iaccheri L, Lazzarin L, Carinci P, Corallini A, Gerosa M, Iuzzolino P, BarbantiBrodano G \& Tognon M (1996) SV40 early region and large T antigen in human 
brain tumors, peripheral blood cells, and sperm fluids from healthy individuals. Cancer Res. Oct 15;56(20):4820-5, ISSN 0008-5472

Lapin BA, Dzhikidze EK, Iakovleva LA, Chumakova MK \& Adzhigitov FI (1965) SV-40 virus infection of monkeys in North Vietnamese jungle Vopr Virusol. MarApr;10(2):226-8. Russia, ISSN 0507-4088

Lapin BA. Chikobava MG (2009a)Detection of SV40 in blood samples from healthy subjects in the Russian Federation by RT-PCR. Vestn Ross Akad Med Nauk. (4):7-10, ISSN 0869-6047

Lapin B A, Chikobava MG (2009b) Epidemiology of SV-40 simian virus in different regions of the Russian federation. Bull Exp Biol Med. Dec;148(6):924-6, ISSN 0007-4888

Lednicky JA, Butel JS (2001): Simian virus 40 regulatory region struc-tural diversity and the association of viral archetypal regulatory regions with human brain tumors. Semin Cancer. Biol. 11: 39 - 47, ISSN 1044-579X

Leithner A, Weinhaeusel A, Windhager R, Schlegl R, Waldner P, Lang S, Dominkus M, Zoubek A, Popper HH \& Haas OA (2002): Absence of SV40 in Austrian tumors correlates with low incidence of mesotheliomas. Cancer Biol Ther 1:375-379, ISSN 1538-4047

Leithner K, Leithner A, Clar H, Weinhaeusel A, Radl R, Krippl P, Rehak P, Windhager R, Haas OA, \& Olschewski H. (2006) Mesothelioma mortality in Europe: impact of asbestos consumption and simian virus 40. Orphanet J Rare Dis. Nov 7;1:44, ISSN $1750-1172$

Levine A, Butel J, Dorries K, Goedert J, Frisque R, Garcea R, Morris A, O'Neill F, \& Shah K. (1998) SV40 as a putative human commensal. Developments in Biological Standardization 94: 245 269, ISSN 0301-5149

López-Rios F, Illei PB, Rusch V, \& Ladanyi M. (2004) Evidence against a role for SV40 infection in human mesotheliomas and high risk of false-positive PCR results owing to presence of SV40 sequences in common laboratory plasmids Lancet, 364 (9440), 1157- 1166, ISSN 0099-3090

Maginnis MS, Atwood WJ. (2009) JC virus : an oncogenic virus in animals and humans? Semin Cancer Biol. Aug;19(4):261-9. Epub 2009 Feb 24. Review, ISSN 1044$579 \mathrm{X}$

Manfredi, J.J, Jianli Dong, Wen-jun Liu, Lois Resnick-Silverman, Rui Qiao, Philippe Chahinian, Marko Saric, Allen R. Gibbs, James I. Phillips, J. Murray, Charles W. Axt en, Robe rt P. Nolan, \& Stuart A. Aaronson (2005) Evidence against a Role for SV40 in Human Mesothelioma. Cancer Res. 65(7): 2602- 2609, ISSN 0008-5472

Mayall F, Barratt K, \& Shanks J (2003) The detection of Simian virus 40 in mesotheliomas from New Zealand and England using real time FRET probe PCR protocols. J. Clin. Pathol. Oct;56(10):728-730, ISSN 0021-9746

Minor P, Pipkin P, Jarzebek Z \& Knowles W (2003) Studies of neutralising antibodies to SV40 in human sera. J Med Virol. Jul;70(3):490-5, ISSN 0146-6615

Murdin AD, Barreto L, Plotkin S (1996): Inactivated poliovirus vaccine: past and present experience. Vaccine 14:735-746.

Padgett BL, Walker DL, ZuRhein GM, Eckroade RJ, Dessel BH (1971) Cultivation of papovalike virus from human brain with progressive multifocal leucoencephalopathy. Lancet. Jun 19;1(7712):1257-60, ISSN 0099-5355 
Paracchini V, Garte S, Pedotti P, Poli F, Frison S, Taioli E (2005) Molecular identification of simian virus 40 infection in healthy Italian subjects by birth cohort. Mol Med. JanDec;11(1-12):48-51.

Peden, K. (2008) Recovery of strains of the polyomavirus SV40 from rhesus monkey kidney cells dating from the 1950s to the early 1960s Virology, 370 (1), 63-76

Rizzo P, Bocchetta M, Powers A, Foddis R, Stekala E, Pass HI, \& Carbone M (2001): SV40 and the pathogenesis of mesothelioma. Semin Cancer Biol. 11: 63-71, ISSN 1044$579 X$

Rizzo P, Di Resta I, Stach R, Mutti L, Picci P, Kast WM, Pass HI, \& Carbone M (1998): Evidence for and implications of SV40-like sequences in human mesotheliomas and osteosarcomas. Dev. Biol. Stand. 94: 33- 40, ISSN 0301-5149

Rizzo P, Resta ID, Powers A, Ratner H, \& Carbone M (1999) Unique strains of SV40 in commercial poliovaccines from 1955 not readily identifiable with current testing for SV40 infection. Cancer Research 59: 6103- 6108, ISSN 0008-5472

Sangar D, Pipkin PA, Wood DJ \& Minor PD (1999): Examination of poliovirus vaccine preparations for SV40 sequences. Biologicals ,27:1-10.

Shah KV (2007) SV40 and human cancer: a review of recent data. Int J Cancer. Jan 15;120(2):215-23. Review, ISSN 0020-7136

Shah K, Nathanson N (1976) Human exposure to SV40: Reviews and Comment.. Am. J. Epidemiol. 103:11-12.

Simon M (2008), Polyomaviruses of Nonhuman Primates: implications for research. Comp. Med. Feb. 58(1): 51- 56, ISSN 1532-0820

Skovranek V (1961): The organization and results of mass vaccination against poliomyelitis in CSSR. In The control of poliomyelitis by live poliovirus vaccine Edited by: Weissfeiler J. Budapest, Akademiai Kiado :41-51.

Sweet BH, Hilleman MR (1960): The vacuolating virus SV40. Proc. Soc.Exper. Biol .Med. 105: 420 - 427,

Schuler F (2006) No evidence for simian virus 40 DNA sequences in malignant non-Hodgkin lymphomas. Int. J. Cancer 118, 498-504, ISSN 0020-7136

Testa JR, Carbone M, Hirvonen A, Khalili K, Krynska B, Linnainmaa K, Pooley FD, Rizzo P, Rusch V \& Xiao, GH (1998) A multi-institutional study confirms the presence and expression of simian virus 40 in human malignant mesothelioma. Cancer Res., 58: 4505-4509, ISSN 0008-5472

Thu GO, Hem LY, Hansen S, Moller B, Norstein J, Nokleby H \& Grotmol T (2006): Is there an association between SV40 contaminated polio vaccine and lymphoproliferative disorders? An age period-cohort analysis on Norwegian data from 1953 to 1997. Int J Cancer 118(8):2035-9, ISSN 0020-7136

Tognon M, Martini F, Iaccheri L, Cultrera R, \& Contini C (2001): Inves-tigation of the simian polyomavirus SV40 as a potential causative agent of human neurological disorders in AIDS patients. J. Med. Microbiol. 50: 165-172, ISSN 0022-2615

Vastag B (2002) Sewage Yields Clues to SV40 Transmission JAMA 288 (11): 1337- 1338, ISSN 0098-7484

Vilchez RA, Madden CR, Kozinetz CA, Halvorson SJ, White ZS, Jorgenson JL, Finch CJ \& Butel JS (2002): Association between simian virus 40 and non-Hodgkin lymphoma. Lancet 359: 817- 823, ISSN 0099-5355 
Viscidi RP, Rollison DE, Viscidi E, Clayman B, Rubalcaba E, Daniel R, Major EO \& Shah KV (2003) Serological cross-reactivities between antibodies to simian virus 40 , BK virus, and JC virus assessed by virus-like-particle-based enzyme immunoassays. Clin Diagn Lab Immunol. Mar;10(2):278-85

Voevodin A. \& Marx PA Simian Virology,2009, Wiley-Blackwell, ISBN-13: 978-0-8138-2432-1, UK

Zekri AR, Bahnassy AA, Mohamed WS, Hassan N, Abdel-Rahman AR, El-Kassem FA \& Gaafar R (2007) Evaluation of simian virus-40 as a biological prognostic factor in Egyptian patients with malignant pleural mesothelioma. Pathol Int. Aug;57(8):493501, ISSN 1320-5463 


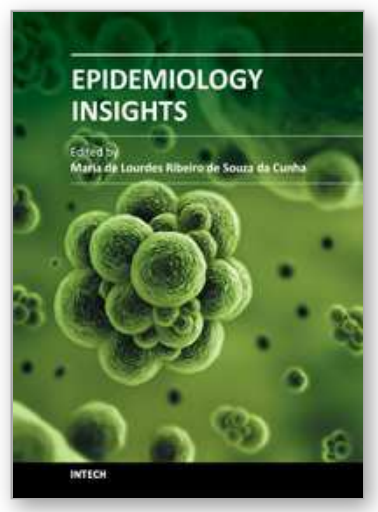

\author{
Epidemiology Insights \\ Edited by Dr. Maria De Lourdes Ribeiro De Souza Da Cunha
}

ISBN 978-953-51-0565-7

Hard cover, 396 pages

Publisher InTech

Published online 20, April, 2012

Published in print edition April, 2012

This book represents an overview on the diverse threads of epidemiological research, brings together the expertise and enthusiasm of an international panel of leading researchers to provide a state-of-the art overview of the field. Topics include the epidemiology of dermatomycoses and Candida spp. infections, the epidemiology molecular of methicillin-resistant Staphylococcus aureus (MRSA) isolated from humans and animals, the epidemiology of varied manifestations neuro-psychiatric, virology and epidemiology, epidemiology of wildlife tuberculosis, epidemiologic approaches to the study of microbial quality of milk and milk products, Cox proportional hazards model, epidemiology of lymphoid malignancy, epidemiology of primary immunodeficiency diseases and genetic epidemiology family-based. Written by experts from around the globe, this book is reading for clinicians, researchers and students, who intend to address these issues.

\title{
How to reference
}

In order to correctly reference this scholarly work, feel free to copy and paste the following:

B. Lapin and M. Chikobava (2012). Epidemiology of Simian Polyomavirus SV40 in Different Areas of Russian Federation (RF), Epidemiology Insights, Dr. Maria De Lourdes Ribeiro De Souza Da Cunha (Ed.), ISBN: 978953-51-0565-7, InTech, Available from: http://www.intechopen.com/books/epidemiology-insights/epidemiologyof-poliomavirus-sv-40-in-different-regions-of-russia

\section{INTECH}

open science | open minds

\author{
InTech Europe \\ University Campus STeP Ri \\ Slavka Krautzeka 83/A \\ 51000 Rijeka, Croatia \\ Phone: +385 (51) 770447 \\ Fax: +385 (51) 686166 \\ www.intechopen.com
}

\author{
InTech China \\ Unit 405, Office Block, Hotel Equatorial Shanghai \\ No.65, Yan An Road (West), Shanghai, 200040, China \\ 中国上海市延安西路65号上海国际贵都大饭店办公楼405单元 \\ Phone: +86-21-62489820 \\ Fax: +86-21-62489821
}


(C) 2012 The Author(s). Licensee IntechOpen. This is an open access article distributed under the terms of the Creative Commons Attribution 3.0 License, which permits unrestricted use, distribution, and reproduction in any medium, provided the original work is properly cited. 